\title{
NPAs in Indian Scheduled Commercial Banks: Origination and Impact on Economy
}

\author{
Sunil B. Kapadia， Venu V. Madhav
}

\begin{abstract}
Mounting non-performing assets (NPAs) in the Indian banking sector has been drawing the attention of policymakers, economists, academicians, and other stakeholders. More particularly, during the last ten years, the rise in NPAs of banks has sent the alarming bell both to the Reserve Bank of India and the Government. Per a few studies, one of the root cause for the huge and gigantic rise in NPAs is the 2008 global financial crisis besides lending to Priority sector. The necessity of provisions and high funding costs has also caused an increase in NPAs while bringing down the profitability of banks. Hence, the consequent impact of NPA includes poor recycling of funds due to the weak deployment of credit which potentially could thwart the financial soundness of the credit system. Higher NPAs not only shakes the confidence of investors, depositors, lenders, etc., but also imperil liquidity, solvency position, profitability, capital adequacy ratio, and so on.

A few measures that are required for management of NPAs like the establishment of monitoring department, reformulation of banks' credit appraisal techniques, among others. The paper examines the trends of NPAs and the factors responsible for mounting NPAs in the banking sector from non-identical aspects. The use of secondary sources of data from authentic websites of RBI, Finance Ministry, and Banks has been made.
\end{abstract}

Keywords: Non-performing assets, Credit appraisal, Priority sector lending, 2008 global financial crisis

\section{INTRODUCTION}

Since the first phase of economic liberalization in 1991, the banking industry has experienced notable changes and hence credit management (Poongavanam, 2011). For a stable financial position in a competitive global business environment (Prasad and Veena, 2011) A callous keeping money framework is key to At whatever economy striving should accomplish development.

The support of a couple non-performing resources (NPA) is a significant one (Rao, 2013) to accomplish a systematic circulation of assets crosswise over existence by decreasing

NPAs speak to the measured "Credit Risk". A segment of the advance portfolio prompting no recuperation or less recuperation results into NPA and it might prompt deferral and disavowal of credit bringing about low off-assume of praise reserves. NPAs are a certain weight on the financial business deciding the presentation of the credit organizations.

Revised Manuscript Received on July 22, 2019.

Sunil B. Kapadia, Ph.D. Scholar, KL University, Vijayawda, India

Dr. Venu V. Madhav, Associate Professor, Department of MBA, KL University, Vijayawda, India. wasteful aspects emerging out of market quarreling.

The high probability of many credit defaults is the indication of high NPAs that guide and change the net-worth and profitability of banks and erodes the value of the asset. Per a few studies, some of the reasons for mounting NPAs are:

- Weak and unfit supervision of loan accounts;

- lack of technical and managerial expertise, and;

- purposeful defaults, on the part of borrowers (Kamini Rai, 2012).

Moreover, in some cases, the violation of RBI directives/circulars which are essential to follow besides approach and attitudes towards lending and recovery of loans are other important facets for an increase in NPAs.

\section{LITERATURE REVIEW}

A relative study comparing NPA of Old Private Sector Banks and Foreign Banks by Kumar (2013) states that Non-Performing Assets (NPAs) have become anissue and problem for the Indian banking sector for more than a decade. A typically high Debt/Gross Domestic Product (GDP) ratio of say, more than 80 to 100 percent as revealed by high leverage in the country could be a forewarning indicator for the likely problem of NPAs (see Ernst \& Young, 2001).

An investigation on the results of need part propels on NPAs by the Department of Banking Supervision (1999), RBI and found that the frequency of NPAs in need segment is a lot higher on the grounds that need segment advances comprise 30-32 percent of the gross bank credit. [RBI Bulletin, LIII (7): 913-93]. The examination made by Bhati (2006) while inspecting the loaning soul for banks in rising economies like India found that because of the administration approaches, banks in India embrace numerous extra dangers when they loan.

Per Siraj K.K. also, P. Sudarsanan Pillai, 2012 the bookkeeping treatment likewise neglected to abuse the issue of NPA, as enthusiasm on advance records were accounted on a collection premise. In his article, the writer has referenced that the Narasimham Committee recognized the NPAs as one of the potential impacts of bad behavior/breaking down of open division banks (Ramu, N., 2009). The examination made by the creator indicates out one of RBI report set up that decrease of NPAs in the financial division ought to be treated as a national need issue to make the Indian financial framework versatile, a lot more grounded and equipped to address the difficulties of globalization (Parul Khanna, 2012). 
The starting point of the issue of mounting NPA's lies in the arrangement of credit hazard the board by the banks - Singh (2013). Per Prasad G.V.B. what's more, Veena (2011) banks are required to make arrangements for NPAs from their present benefits, along these lines NPAs disastrously affect the arrival on resources in the accompanying ways.

\section{METHODOLOGY}

This study is descriptive in nature. The author has made use of secondary data which are sourced from authentic registered websites of SCBs, CRISIL, Ernst \& Young, CSO-MoSPI, MoF, RBI, articles, journals, documents, printed literature, the published reports, and other online databases.

\section{DISCUSSION AND ANALYSIS}

A vast amount of bank's resources is blocked due to provisioning and write-off, a rising of such bad loans and thus it becomes idle for further lending. Moreover, the requirement of additional capital, weakening of profits are some major problems created by rising non-performing assets (NPAs) in scheduled commercial banks in the country.

The following table(s) point out how the NPA level has risen in SCBs in Indian banking, particularly post-2008 global financial crisis.

Table: 1.1 Gross Advances and Gross NPAS of SCBs

\begin{tabular}{|l|c|c|c|}
\hline $\begin{array}{l}\text { Financial } \\
\text { Year }\end{array}$ & $\begin{array}{c}\text { Gross } \\
\text { Advances }\end{array}$ & $\begin{array}{c}\text { Gross NPA } \\
\text { (Amount) }\end{array}$ & $\begin{array}{c}\text { Gross } \\
\text { NPA } \\
(\%)\end{array}$ \\
\hline $2001-02$ & 6809.58 & 708.61 & 10.4 \\
\hline $2005-06$ & 15513.78 & 510.97 & 3.3 \\
\hline $2009-10$ & 35449.65 & 846.98 & 2.4 \\
\hline $2013-14$ & 68757.48 & 2641.95 & 3.8 \\
\hline
\end{tabular}

Source: dbie.rbi.org.in

Table: 1.2 Net Advances and Net NPAS of SCBs (Amount in Rupees Billion)

\begin{tabular}{|l|c|c|c|}
\hline $\begin{array}{l}\text { Financial } \\
\text { Year }\end{array}$ & $\begin{array}{c}\text { Net } \\
\text { Advances }\end{array}$ & $\begin{array}{c}\text { Net NPA } \\
\text { (Amount) }\end{array}$ & $\begin{array}{c}\text { Net NPA } \\
(\%)\end{array}$ \\
\hline $2001-02$ & 6458.59 & 355.54 & 5.5 \\
\hline $2005-06$ & 15168.11 & 185.43 & 1.2 \\
\hline $2009-10$ & 34970.92 & 387.23 & 1.1 \\
\hline $2013-14$ & 67352.32 & 1426.57 & 2.1 \\
\hline & & & \\
\hline
\end{tabular}

Source: dbie.rbi.org.in
Both tables (1.1 \& 1.2) show that Gross NPA and Net NPA amount (in absolute terms) have increased from 2001-02 level to 2013-14 level, and continue rising _ -

Table: 1.3 Select top ten SCB's Provision/Write-offs (Rs. In Crore)

\begin{tabular}{|l|c|c|}
\hline Banks & $\begin{array}{c}\text { FY: 2017- } \\
\mathbf{1 8}\end{array}$ & $\begin{array}{c}\text { FY: 2016- } \\
\mathbf{1 7}\end{array}$ \\
\hline PSBs & & \\
\hline State Bank of India & 40196 & 27757 \\
\hline Bank of Baroda & 14212 & 7680 \\
\hline $\begin{array}{l}\text { Punjab National } \\
\text { Bank }\end{array}$ & & 15881 \\
\hline- & 0 & 0 \\
\hline Bank of India & 11483 & 8098 \\
\hline Canara Bank & 14285 & 7236 \\
\hline $\begin{array}{l}\text { Private Sector } \\
\text { Banks }\end{array}$ & & \\
\hline HDFC Bank & 12959 & 7126 \\
\hline ICICI Bank & 19865 & 16160 \\
\hline Kotak Bank & 1858 & 1797 \\
\hline Axis Bank & 16281 & 11139 \\
\hline- & 0 & 0 \\
\hline TOTAL & & $\mathbf{1 0 2 8 7 4}$ \\
\hline
\end{tabular}

Source: PublishedAnnual reports of the respective bank(s).

The above table is self-explanatory and the figure speaks for themselves. Compared to FY 16-17, NPA provisions and Write-offs have increased by 30 percent plus in FY 17-18 in just twelve months. This is scary and forbidding trends; the situation needs some remedy in the form of quick action both from the Government and the RBI end.

Table: 1.4 Gross \& Net NPAs of all Banks for: 2005-06 to 2016-17 (Rs. Billion)

\begin{tabular}{|l|c|c|c|c|c|}
\hline $\begin{array}{l}\text { Bank } \\
\text { Group }\end{array}$ & Year & $\begin{array}{l}\text { Gross NPA } \\
\text { (Amount) }\end{array}$ & $\begin{array}{l}\text { Gross NPA } \\
(\%) \\
\text { Advances }\end{array}$ & $\begin{array}{l}\text { Net NPA } \\
\text { (Amount) }\end{array}$ & $\begin{array}{l}\text { Net NPA } \\
(\%) \\
\text { Advances }\end{array}$ \\
\hline SCBs & $2005-06$ & 517.53 & 3.3 & 185.43 & 1.2 \\
\hline PSBs & $2005-06$ & 421.17 & 3.7 & 145.66 & 1.3 \\
\hline $\begin{array}{l}\text { Old } \\
\text { Pvt. } \\
\text { Banks }\end{array}$ & $2005-06$ & 37.59 & 4.4 & 13.75 & 1.7 \\
\hline $\begin{array}{l}\text { New } \\
\text { Pvt. } \\
\text { Banks }\end{array}$ & $2005-06$ & 75.99 & 2.4 & 31.70 & 1.0 \\
\hline $\begin{array}{l}\text { Foreign } \\
\text { Banks }\end{array}$ & $2005-06$ & 20.37 & 2.1 & 8.08 & 0.8 \\
\hline SCBs & $2016-17$ & 7902.68 & 9.3 & 4330.10 & 5.3 \\
\hline PSBs & $2016-17$ & 6847.33 & 11.7 & 3830.89 & 6.9 \\
\hline $\begin{array}{l}\text { Old } \\
\text { Pvt. } \\
\text { Banks }\end{array}$ & $2016-17$ & & & & \\
\hline $\begin{array}{l}\text { New } \\
\text { Pvt. } \\
\text { Banks }\end{array}$ & $2016-17$ & 919.15 & 4.1 & 477.80 & 2.2 \\
\hline $\begin{array}{l}\text { Foreign } \\
\text { Banks }\end{array}$ & $2016-17$ & 138.21 & 4.0 & 21.41 & 0.6 \\
\hline
\end{tabular}

Source: Handbook of Statistics on the Indian Economy, RBI (2017-18).

The above table has revealedthat Gross NPA level for both SCBs and PSBs have increased by almost 3 times in 2016-17 from 2005-06 in an 11-year period. However,Net NPA level for both SCBs and PSBs 
have increased by 5 times in 2016-17 from 2005-06 in an 11-year period. Whereas both Gross NPA \& Net NPA level has increased by two times in the case of New Private Sector banks in 2016-17 from 2005-06 level in an 11-year period.

Further to the above analysis few more important statistics about Bank's Net NPA

1. SBI's Net NPA to Net Advances have risen to 5.73\% in 2017-18 from $1.79 \%$ in 2008-09.

2. PNB's Net NPA rose to $7.81 \%$ in $2016-17$ from $1.52 \%$ in $2011-12$.

Table: 1.5 Composition of NPAs OF Public Sector Banks from 2004 to 2013

(Rs. Billion) - As on March 31

\begin{tabular}{|c|c|c|c|c|c|c|c|c|}
\hline $\begin{array}{l}\text { Bank } \\
\text { Name }\end{array}$ & Year & $\begin{array}{l}\text { Priorit } \\
\text { y } \\
\text { Sector }\end{array}$ & & $\begin{array}{l}\text { Non- } \\
\text { Prior } \\
\text { ity } \\
\text { Secto } \\
\text { r }\end{array}$ & & $\begin{array}{l}\text { Publ } \\
\text { ic } \\
\text { Sect } \\
\text { or }\end{array}$ & & $\begin{array}{l}\text { Gros } \\
\text { s } \\
\text { NPA } \\
\text { s }\end{array}$ \\
\hline & & $\begin{array}{l}\text { Amoun } \\
t\end{array}$ & $\begin{array}{l}\text { \% } \\
\text { shar } \\
\text { e }\end{array}$ & $\begin{array}{l}\text { Amo } \\
\text { unt }\end{array}$ & $\begin{array}{l}\% \\
\text { share }\end{array}$ & $\begin{array}{l}\text { Amo } \\
\text { unt }\end{array}$ & $\begin{array}{l}\% \\
\text { sh } \\
\text { ar } \\
\text { e }\end{array}$ & $\begin{array}{l}\text { Amo } \\
\text { unt }\end{array}$ \\
\hline \multirow{3}{*}{$\begin{array}{l}\text { Nation } \\
\text { alised } \\
\text { Banks }\end{array}$} & 2005 & 163.81 & $\begin{array}{c}51.1 \\
7\end{array}$ & $\begin{array}{c}153.4 \\
6\end{array}$ & 47.94 & 2.83 & $\begin{array}{c}0.8 \\
8\end{array}$ & $\begin{array}{c}320.0 \\
9\end{array}$ \\
\hline & 2008 & 163.85 & $\begin{array}{c}67.2 \\
1\end{array}$ & 77.93 & 31.96 & 2.02 & $\begin{array}{c}0.8 \\
3\end{array}$ & $\begin{array}{c}243.8 \\
0\end{array}$ \\
\hline & 2013 & 404.86 & $\begin{array}{c}42.2 \\
1\end{array}$ & $\begin{array}{c}553.5 \\
9\end{array}$ & 57.71 & 0.78 & $\begin{array}{c}0.0 \\
8\end{array}$ & $\begin{array}{c}959.2 \\
2\end{array}$ \\
\hline \multirow[t]{3}{*}{$\begin{array}{l}\text { SBI } \\
\text { Group } \\
\end{array}$} & 2005 & 70.17 & $\begin{array}{c}47.3 \\
9 \\
\end{array}$ & 76.24 & 51.48 & 1.68 & $\begin{array}{c}1.1 \\
3\end{array}$ & $\begin{array}{c}148.0 \\
8\end{array}$ \\
\hline & 2008 & 89.02 & $\begin{array}{c}58.4 \\
9\end{array}$ & 62.22 & 40.88 & 0.97 & $\begin{array}{c}0.6 \\
3\end{array}$ & $\begin{array}{c}152.2 \\
0\end{array}$ \\
\hline & 2013 & 264.42 & $\begin{array}{c}44.0 \\
9\end{array}$ & $\begin{array}{c}334.9 \\
4\end{array}$ & 55.85 & 0.31 & $\begin{array}{c}0.0 \\
5\end{array}$ & $\begin{array}{c}599.6 \\
7\end{array}$ \\
\hline \multirow[t]{3}{*}{ PSBs } & 2005 & 233.97 & $\begin{array}{c}49.9 \\
8\end{array}$ & $\begin{array}{c}229.6 \\
9\end{array}$ & 49.06 & 4.50 & $\begin{array}{c}0.9 \\
6\end{array}$ & $\begin{array}{c}468.1 \\
7\end{array}$ \\
\hline & 2008 & 252.87 & $\begin{array}{c}63.8 \\
5\end{array}$ & $\begin{array}{c}140.1 \\
5\end{array}$ & 35.39 & 2.99 & $\begin{array}{c}0.7 \\
5\end{array}$ & $\begin{array}{c}396.0 \\
0\end{array}$ \\
\hline & 2013 & 669.28 & $\begin{array}{c}42.9 \\
3\end{array}$ & $\begin{array}{c}888.5 \\
3\end{array}$ & 57.00 & 1.08 & $\begin{array}{c}0.0 \\
7\end{array}$ & $\begin{array}{c}1558 . \\
90\end{array}$ \\
\hline
\end{tabular}

The Gross NPA amount has increased markedly (in absolute terms) in the year 2013 from 2005 as can be seen from the above table.

Few other internal and external factors that have also played its role in the rise in NPA level of commercial scheduled banks. We narrate hereunder some important factors:

1. Relaxed and loose credit management and monitoring.

2. Rerouting of funds for modernization, diversification, expansion.

3. Time and cost overrun during the project implementation stage.

4. Failure in product marketing and or subservient quality compared to competitors.

5. Less than requisite pick up in domestic growth and declining exports.

6. Cancellation of coal blocks.

7. Delay in the completion about receivables because of repressed demand, diminished advertises confidence, and so on.

8. Tightness in the steel segment because of instability in the costs from claiming steel, low ability use Also Shabby imports from different nations.
Source: Department of Banking Supervision, RBI.

9. Issues in obtaining raw materials.

10. Low demand and global commodity price cycles.

11. Mismatching in fund utilization - e.g. fund borrowed for long-term used for a short-term purpose.

12. The unforeseen and abrupt crashing of capital markets thereby inability to raise funds.

13. Failure to identify and acknowledge early warning signals shown by standard assets.

Table: 1.6 NPAs recovered by SCBs through Various Channels (Amount in Rs. Crores)

\begin{tabular}{|c|c|c|c|c|c|}
\hline $\begin{array}{l}\text { Financial } \\
\text { Year }\end{array}$ & & $\begin{array}{l}\text { One time } \\
\text { Settlement/ } \\
\text { Compromise } \\
\text { Scheme }\end{array}$ & $\begin{array}{l}\text { Lok } \\
\text { Adalats }\end{array}$ & DRTs & $\begin{array}{l}\text { SARFAESI } \\
\text { Act }\end{array}$ \\
\hline \multirow[t]{3}{*}{ 2003-04 } & $\begin{array}{l}\text { No. of } \\
\text { cases } \\
\text { referred }\end{array}$ & 139562 & 186100 & 7544 & $2661 \#$ \\
\hline & $\begin{array}{c}\text { Amount } \\
\text { involved }\end{array}$ & 1510 & 1063 & 12305 & 7847 \\
\hline & $\begin{array}{c}\text { Amount } \\
\text { recovered }\end{array}$ & 617 & 149 & 2117 & 1156 \\
\hline \multirow[t]{3}{*}{ 2007-08 } & $\begin{array}{c}\text { No. of } \\
\text { cases } \\
\text { referred }\end{array}$ & - & 186535 & 3728 & $83942 \#$ \\
\hline & $\begin{array}{l}\text { Amount } \\
\text { involved }\end{array}$ & - & 2142 & 5819 & 7263 \\
\hline & $\begin{array}{c}\text { Amount } \\
\text { recovered }\end{array}$ & - & 176 & 3020 & 4429 \\
\hline \multirow[t]{3}{*}{ 2011-12 } & $\begin{array}{c}\text { No. of } \\
\text { cases } \\
\text { referred }\end{array}$ & - & 476073 & 13365 & 14099\# \\
\hline & $\begin{array}{l}\text { Amount } \\
\text { involved }\end{array}$ & - & 1700 & 24100 & 35300 \\
\hline & $\begin{array}{l}\text { Amount } \\
\text { recovered }\end{array}$ & - & 200 & 4100 & 10100 \\
\hline
\end{tabular}

Source: Report on Trend and Progress of Banking in India Various issues, RBI.

It is clear from the above table that amount recovered is very low when compared with many cases that have been referred to, particularly in Lok Adalats.

The higher level of NPAs is also due to more forceful approaches of the banks in their lending they may end up in driving riskier loans. However, there is anallegation that may have developed expertise in managing the credit risk as they concentrate on credit management and hence may sometimes exhibit a lower level of NPAs. Therefore, the role of lending forcefulness in causing the increase in NPAs is still murky.

Per Dr. Raghuram Rajan (ex-RBI Governor) while replying to Indian Parliamentary Committee (Sep-2018) said that a Bigger amount for terrible loans were originated in the period 2006-2008 The point when past foundation ventures for example, energy plants required been finished on time and inside plan What's more financial development might have been solid. Banks make mistakes during such times.

They look at past growth and performance and reckon to the future. So, they are willing to accept less promoter equity and higher leverage in projects. Further, in some cases, banks without doing their own due diligence signed up to lend based on project reports by the promoter's investment bank.

\section{CONCLUSION}


The position of the Indian banking sector has been aggravated by the rising level in NPAs. Several experiments have been tried to curb NPAs (viz., BIFR/SICA, Lok Adalats, DRTs, OTS, SARFAESI, etc.) yet no concrete solution is found in tackling NPAs (refer Table 1.6). The spirits of bankers have suppressed since The legitimacy about both DRT/ Securitization demonstration might have been tested and at present hangs in situation.

A standout amongst that principle reason for NPAs in the saving money division will be the guided credits framework under which business banks need aid required will supply 40 percent about their credit on necessity parts may be. Loaning on necessity division will be vital and more ought to make that groundwork for a operational restructuring from claiming banks, in spite of the fact that the NPAs in the necessity parts would lessened insignificantly.

The problem of NPAs can be seized with

- A risk management mechanism and appropriate credit appraisal for its constructive implementation in the banking sector.

- The prudential norms laid down by the RBI must equip the banking system to reduce if not completely to keep away from the problem of NPAs.

By putting in place proper and precise credit appraisal mechanisms the NPAs can be addressed considerably at the budding stage of credit consideration itself.

Prof Sridhar Acharyulu, Central Information Commissioner (CIC) has directed (Sep-2018) the Reserve Bank of India (RBI), the finance ministry, and the ministry of statistics \& implementation to make public, the names of those bank loan defaulters whose unpaid loans amount to Rs. 50 crore and above. This order is a sequel to the information sought by an RTI applicant.

The foregoing discussion has aptly elaborated the issues and perspectives on the performance of the banking sector. The problems highlighted here are essential for the financial stability of the economy that needs to be adhered to on an urgent basis. This is particularly important on the eve of the introduction of Basel III norms by RBI to the banks in 2019, and hence, NPA level of this enormousness need to be brought under control and thus there is an urgency to recapitalize select PSBs in a time-bound program.

Fair and acceptable recapitalization of banks is necessary and should be ensured, although banks have already provisioned for a part of these exposures, given the quantum of haircut involved. To kick-start of the next investment cycle, Quick resolution of the NPA stress could well be a better solution.

In the recent past, those administration need uncovered an Rs. 2. 11 lakh crore money implantation want to those PSBs, including through bonds, in the next two a considerable length of time. tackling this major problem. With the establishment of National Company Law Tribunal (NCLT), there is hope and buoyancy that resolution process could provide a much-needed solution, especially in case of defaulting promoters who do not agree with a plan with its banker in stipulated 180 days.

\section{LIMITATION}

The study is limited to select variables and confined to select period. Any limitation to the study and the analysis due to circumstances beyond one's control is unintentional.

\section{REFERENCES}

1. Poongavanam, (2011). "NPAs: Issues, Causes and Remedial Solution." AJMR

2. Prasad and D. Veena, (2011). "NPAs reduction strategies for Commercial Banks in India." IJMBS

3. M. Rao \& A. Patel, (Mar-2015). "A study on NPAs management in banks.” JMS, Vol. 5 No.1

4. P T Kumar (2013). "A comparative study of old private banks and foreign banks."

5. Ernst \& Young, (2002). "Non-Performing Loan Report.” New York

6. Shyam Bhati, (Dec-2006). "Trust between Branch Managers and Loans Officers of Indian banks." IRBRP, Vol. 2, No. 4

7. Siraj K.K. and P. Sudarsanan Pillai, (2012). "A study on the performance of NPAs of Indian banking during post millennium period.” IJBM

8. Ramu, N., (2009). "Dimensions of NPAs in Urban Co-op Banks in Tamilnadu." GBR, Sage Publications

9. Parul Khanna, (Apr-Jun, 2012). "Managing NPAs in Commercial Banks." Gian Jyoti E-Journal Vol. 1, Issue 3

10. Vivek R. Singh, (Mar-2016). "A study of NPAs of Commercial Banks and its recovery in India." Annual Research Journal of SCMS, Pune. Vol.4

11. Ms. Asha Singh, (Sep-2013). "Performance of NPAs in Indian Commercial Banks." IJMFSMR, Vol. 2, No. 9

12. Dr. Sushama Yadav, (Jan-2014). "NPAs: Rising trends and Preventive measures in Indian banking sector." IJARCMS Vol. 2, Issue-1

13. Samir \& D. Kamra (Jun-2013). "A comparative analysis of NPAs of selected commercial banks in India." IJM Vol. 3, No. 1

14. S. Das \& A. Dutta (Nov-2014). "A study on NPAs of public sector banks in India.” IOSR-JBM Vol. 16, Issue 11

15. RBI Bulletin, 1999

16. RBI published data for $2015-16$

17. Financial Stability Report, RBI (Dec-15 \& Dec-17)

18. Handbook of Statistics on the Indian Economy, RBI (2017-18)

19. Published annual reports of select PSBs and Private Banks (2016-17 and 2017-187) CRISIL Report, Aug-2017 